\title{
Artykuł 55a ustawy o Instytucie Pamięci Narodowej - Komisji Ścigania Zbrodni przeciwko Narodowi Polskiemu w relacji do art. 55 tej ustawy oraz art. 133 Kodeksu karnego ${ }^{1}$
}

Article 55a of the Act on The Institute of National Remembrance - Commission for the Prosecution of Crimes against the Polish Nation in relation to Article 55 of this act and Article 133 of the Penal Code (BAS-421/18): The purpose of this opinion is to determine the relation between Article 133 of the Penal Code and Article 55 of the Act on The Institute of National Remembrance. The statutory features of these punishable acts have been analysed. Article 133 of the Penal Code penalizes a public insult of the Polish Nation (in a broad, constitutional sense of that term). According to Article 55 of the Act on The Institute of National Remembrance it is prohibited to deny, publicly and contrary to the facts, Nazi crimes, communist crimes or other crimes against peace, humanity or war crimes, perpetrated on persons of Polish nationality or Polish citizens of other nationalities. Article 55a of the mentioned Act protects good reputation as a part of dignity of the Polish Nation and the Polish State. Different legal norms of behavior are described in each of these provisions - the scope of criminalisation is different. Neither Article 133 of the Penal Code, nor Article 55 of the Act on The Institute of National Remembrance match all punishable features provided by Article 55a of the Act on The Institute of National Remembrance.

Keywords: Institute of National Remembrance, Penal Code, criminal law protection of dignity of the Polish Nation and the Republic of Poland

Słowa kluczowe: Instytut Pamięci Narodowej, Kodeks karny, prawnokarna ochrona godności Narodu Polskiego i Rzeczypospolitej Polskiej

Doktor hab. nauk prawnych, prof. Kujawsko-Pomorskiej Szkoły Wyższej w Bydgoszczy; alicja.grzeskowiak@wp.pl.

Ustalenie relacji, jakie zachodzą między przepisami art. 133 Kodeksu karnego ${ }^{2}$ oraz art. 55 ustawy o Instytucie Pamięci Narodowej - Komisji Ścigania Zbrodni

Opinia sporządzona 8 marca 2018 r. na zlecenie Biura Analiz Sejmowych; BAS 421/18.

2 Ustawa z 6 czerwca 1997 r. - Kodeks karny, t.j. Dz.U. 2017, poz. 2244, ze zm.; dalej: k.k. 
przeciwko Narodowi Polskiemu (dalej: ustawa o IPN), a art. 55a tej ustawy wymaga przede wszystkim dokonania analizy ustawowych znamion tych czynów zabronionych. Dopiero porównanie zakresów kryminalizacji ustalonych przez ustawodawcę dla każdego ze wskazanych typów przestępstw, zrekonstruowanych z ustawowych znamion każdego z nich, może dać podstawę twierdzeniu o zasadności lub zbędności odrębnej penalizacji zachowania opisanego w art. 55a ustawy o IPN.

1. Przepis art. 133 k.k. określa przestępstwo publicznego znieważenia Narodu lub Rzeczypospolitej Polskiej. Umiejscowienie go w rozdziale XVII Kodeksu karnego wskazuje, że rodzajowym dobrem chronionym jest Rzeczpospolita Polska. Zgodnie z art. 1 Konstytucji RP jest ona dobrem wspólnym wszystkich obywateli, co tłumaczy decyzję ustawodawcy o potrzebie prawnokarnej ochrony Rzeczypospolitej jako wartości konstytucyjnej.

Indywidualnym dobrem chronionym przez przepis art. 133 k.k. jest cześć i szacunek należny „Narodowi” i Rzeczypospolitej Polskiej ${ }^{3}$. Mimo że ustawodawca nie dookreślił, o jaki naród chodzi, nie ma wątpliwości, że dobrem chronionym jest „Naród Polski”. Problemem w tym kontekście podnoszonym w literaturze karnistycznej jest treść tego pojęcia, stanowiącego ustawowe znamię przestępstwa z art. 133 k.k. Na ogół wskazuje się, idąc za sformułowaniem zawartym w preambule Konstytucji RP, że chodzi tu o polityczne rozumienie narodu, co oznacza, że naród to ogół obywateli. Takie pojmowanie narodu jest utrwalone w piśmiennictwie od dawna. S. Estreicher w odniesieniu do posługującej się tym terminem Konstytucji marcowej pisał, że: Ów teoretyczny wedle konstytucji podmiot suwerenności w państwie czyli piastun władzy zwierzchniej, ów „naród” polski, jest narodem oczywiście nie w znaczeniu etnograficznem, ale politycznem, jest narodem pojętym jako ogół wszystkich obywateli należących do państwa polskie$g^{4}$. W takim znaczeniu interpretowano pojęcie narodu występujące w Kodeksie karnym z 1932 r. ${ }^{5}$. J. Makarewicz wskazywał, że pojęcie „Naród” występujące w Kodeksie karnym jest zsynchronizowane z takim pojęciem używanym w Konstytucji z 1921 r. Identyfikując pojęcie narodu z ogółem obywateli, Makarewicz podkreślał, by nie mylić go z pojęciem narodowości, gdyż obraza narodu dotyczy ogółu społeczeństwa tworzącego państwo polskie, niezależnie od tego: $z$ jakich pierwiastków etnicznych społeczeństwo to się składa . Podkreślał, że jest zadaniem sędziego rozstrzygnięcie, czy zamiar sprawcy był skierowany: na obrazę społeczeństwa polskiego jako całości, społeczeństwa tworzącego fundament dla prawno-

3 K. Wiak [w:] Kodeks karny. Komentarz, red. A. Grześkowiak, K. Wiak, Warszawa 2018, s. 812.

4 S. Estreicher, Zasada zwierzchnictwa narodu [w:] Nasza Konstytucja, Kraków 1922, s. 41.

5 Na przykład J. Makarewicz, Kodeks karny z komentarzem, Lwów 1938, s. 402, 403.

6 Ibidem, s. 405. 
-państwowej konstrukcji, czy też chodziło o dotknięcie danej jednostki lub choćby jakiejś grupy jednostek poprzez znieważenie grupy etnicznej, do której jednostki te należą ${ }^{7}$. Podobnie uważał L. Peiper, także wyraźnie wiążąc to pojęcie z literą Konstytucji RP. Natomiast W. Makowski łączył naród z państwem, podkreślając, że jest on: żywym odpowiednikiem organizacji państwowej.

$\mathrm{Na}$ gruncie współczesnej doktryny prawa karnego dominuje pogląd, wywiedziony z preambuły Konstytucji RP, że naród oznacza wszystkich obywateli RP' Jednak nie jest to jedyna interpretacja pojęcia „naród” na tle przepisu art. 133 k.k. Szeroką wykładnię tego pojęcia przedstawił Trybunał Konstytucyjny, który w wyroku z 21 września 2015 r., sygn. akt K 28/13, rekonstruując treść pojęcia „naród”, odwołał się nie tylko do preambuły Konstytucji RP, ale i do innych jej przepisów, w których to pojęcie występuje. Słusznie wskazał, że, wyprowadzając treść pojęcia „naród” z Konstytucji RP, nie można ograniczać się jedynie do tekstu preambuły, gdyż zwrot ten występuje w tekście Konstytucji także w innych kontekstach, wpływających na jego zakres treściowy. Powołując się na art. 5, 6 i 35 Konstytucji RP, Trybunał Konstytucyjny wskazał, że: ustrojodawca traktuje naród polski (pisany małymi literami) jako wspólnotę nie tyle etniczna ( $w$ ścisłym znaczeniu „wspólnoty krwi”, co byłoby bezprzedmiotowe wobec migracji i mieszania się różnych narodowości zarówno w wielonarodowej I i II Rzeczypospolitej, jak i w wyniku wojen i przemarszów obcych armii), ile kulturowa. Tę zaś definiuje się jako trwająca przez pokolenia wspólnotę związana wielorakimi więziami - między innymi krwi, języka, kultury, religii, $w$ której $w$ różnych okolicznościach $i$ czasach poszczególne z tych więzi uznawane sa za pierwszoplanowe ${ }^{10}$.

W piśmiennictwie niektórzy autorzy, przyjmując, że naród to ogół obywateli polskich, dodają, że pojęcie to obejmuje nie tylko obywateli polskich żyjących w kraju, ale również i poza jego granicami. Ponadto do czysto normatywnego określenia narodu, i nie wychodząc poza kryterium obywatelstwa, dodaje się czasami pewne cechy będące spoiwem narodu jako wspólnoty obywateli. P. Kardas przez naród - na tle art. 133 k.k. - rozumie: historycznie ukształtowana, trwała wspólnotę powstała na gruncie wspólnych losów dziejowych, wspólnej gospodarki, wspólnych instytucji politycznych, charakteryzująca się istnieniem poczucia państwowego jako podstawowego składnika świadomości grupowej, które uzewnętrz-

Ibidem.

W. Makowski, Kodeks karny, Warszawa 1933, s. 398.

9 Na przykład K. Wiak [w:] Kodeks karny, op. cit., s. 812; S. Hoc [w:] System prawa karnego, t. 8, red. L. Gardocki, Warszawa 2012, s. 115; A. Michalska-Warias [w:] Kodeks karny. Komentarz, red. T. Bojarski, Warszawa 2008, s. 240; J. Kulesza [w:] Kodeks karny. Część szczególna, t. I, Komentarz do artykułów 117-221, red. M. Królikowski, R. Zawłocki, 2017, Legalis, s. 125.

10 Wyrok TK z 21 września 2015 r., sygn. akt K 28/13. 
niane jest przez fakt posiadania przez dana osobe obywatelstwa Rzeczypospolitej Polskiej ${ }^{11}$.

W piśmiennictwie zauważa się jednak, że w takim ujęciu do „Narodu Polskiego" nie zalicza się Polaków z pochodzenia, żyjących poza Polską, niemających obywatelstwa polskiego. Pogląd taki pozostawia poza zakresem tego pojęcia dużą liczbę osób żyjących poza granicami Polski, w tym także tych, którzy utracili obywatelstwo przez zabranie Polsce ziem Kresów Wschodnich, jednak zachowali poczucie przynależności do „Narodu Polskiego”. Rację ma J. Giezek, który, odnosząc się do przyjmowanej w doktrynie wykładni pojęcia „naród”, na tle art. 133 k.k. zwraca uwagę, że: [n] ie można jednak tracić z pola widzenia, że ujęcie to stwarzać może problemy w odniesieniu do tych wypowiedzi, które znieważają Polonię zagraniczną. Część tzw. polonusów, zamieszkujących przykładowo Stany Zjednoczone czy Kanadę, a wywodzacych się z fal emigracji XIX-wiecznej czy powojennej, to osoby nieposiadające obywatelstwa polskiego. Z kolei współcześni emigranci, przebywajacy zarobkowo poza granicami Rzeczypospolitej, w przeważajacej części zachowują status obywateli polskich. Pod względem obywatelstwa Polonia stanowi zatem społeczność mieszaną. Wydaje się zaś aksjologicznie uzasadnione, by ochrona komentowanego przepisu obejmowała wszystkie osoby, także zamieszkujace na emigracji, które czują przynależność do „Narodu Polskiego”12.

Na tę kwestię zwrócił również uwagę Trybunał Konstytucyjny, podkreślając w przywołanym wyżej wyroku, że w piśmiennictwie: rozumie się przez naród polski (...) trwała wspólnotę (czy też społeczność) mówiąca językiem polskim, zwiazana wspólną przeszłością (historycznie ukształtowana) i kultura, mająca wspólne interesy polityczne i gospodarcze, żywiąca poczucie odrębności od innych narodów oraz nacechowana istnieniem poczucia państwowego (pragnieniem posiadania i umacniania własnego państwa), urzeczywistnionego przez posiadanie polskiego obywatelstwa. Trybunał zauważył przy tym, że: sprzeczne sa natomiast stanowiska co do zaliczania do Narodu Polskiego w rozumieniu kk [Kodeksu karnego dopisek red.] i kw [Kodeksu wykroczeń - dopisek red.] osób deklarujących polska narodowość, ale nieposiadających obywatelstwa polskiego (problemem jest tu aksjologicznie nieuzasadniona nierówna ochrona Polonii - osób zamieszkałych na emigracji, poczuwających się do przynależności do narodu polskiego, ale zróżnicowanych pod względem posiadanego obywatelstwa, a ściśle osób nieposiadajacych obywatelstwa polskiego $z$ racji zmiany pokoleniowej albo pozbawienia go przez władze komunistyczne. Niektórzy konstytucjonaliści również dostrzegają, że określenie „Narodu Polskiego” zawarte w preambule Konstytucji RP jest niepełne i nie może być zacieśnione tylko do ogółu obywateli polskich. W literaturze można odnaleźć pogląd, według którego obywatele aktualnie tworzący „Naród

11 P. Kardas [w:] Kodeks karny. Część szczególna, t. II, Komentarz do art. 117-277, Warszawa 2008, s. 121.

12 J. Giezek, Kodeks karny. Komentarz. Czesść szczególna, 2008, LEX. 
Polski” pozostają: złączeni więzami wspólnoty z naszymi rodakami rozsianymi po świecie (...), więc pojmowanie narodu wykracza poza aktualna sumę obywateli $R P$. Jest to zarazem potwierdzeniem, że twórcy wstępu nie zamierzali formułować prawniczo precyzyjnych definicji narodu polskiego, nie byłoby to zreszta ani możliwe, ani potrzebne (...). Konstytucyjne pojęcie narodu polskiego nie może być zacieśniane tylko do ogółu osób narodowości polskiej ${ }^{13}$. Na niebezpieczeństwa związane z ograniczaniem zakresu pojęcia „naród” jedynie do wspólnoty politycznej zwracał uwagę także B. Banaszak ${ }^{14}$.

W literaturze okresu międzywojennego dotyczącej prawa politycznego W. Komarnicki podkreślał, że naród jest osobą różną od państwa, jak i od wchodzących w jego skład jednostek ${ }^{15}$. To naród określa państwo, nadaje mu indywidualne piętno ${ }^{16}$. Konstytutywnym elementem narodu jest ciągłość tradycji i aspiracji ${ }^{17}$.

Naród na tle art. 133 k.k. to więc nie tylko prosta suma pojedynczych obywateli, ale to podmiot zbiorowy, całość połączona wspólną tożsamością, kulturą, historią, poczuciem przynależności do Narodu Polskiego, nie ograniczona do osób mających polskie obywatelstwo, co pozwoli zaliczać do Narodu Polskiego również osoby żyjące poza granicami Rzeczypospolitej, a więc osoby niemające polskiego obywatelstwa, ale mające poza polskim pochodzeniem duchowe i kulturowe więzy z ojczyzną.

Pojęcie „Rzeczpospolita” na gruncie art. 133 k.k. nie budzi wątpliwości, oznacza bowiem nazwę państwa polskiego. Ale znowu należy podkreślić, że chodzi o państwo jako całość, a nie o jego poszczególne elementy organizacyjne. $\mathrm{Na}$ ogół w komentarzach przytacza się jako wykładnik tego pojęcia interpretację zawartą w komentarzu do Kodeksu karnego L. Peipera, podkreślającego, że na pojęcie państwa składają się trzy czynniki - terytorium, ludność i suwerenna władza. Państwo według tego autora to jednostka występująca we współżyciu narodów, czyli w sferze prawa międzynarodowego, tudzież twór polityczny ${ }^{18}$.

Dla ustalenia właściwego zakresu kryminalizacji zachowania zabronionego przepisem art. 133 k.k., a równocześnie ustalenia zakresu ochrony Narodu i Rzeczypospolitej Polskiej na jego podstawie, istotne znaczenie ma także właściwe określenie indywidualnego dobra chronionego. Na ogół przyjmuje się, że jest nim poczucie własnej wartości. W. Kulesza natomiast wywodzi, że ten: przepis prawa karnego chroni godność człowieka - rozumiana jako stan dany każdemu podmiotowi - przed takimi naruszeniami, które według zdeterminowanych kulturowo i powszechnie przyjętych ocen stanowia wyraz pogardy dla człowieka nie-

13 Konstytucja Rzeczypospolitej Polskiej. Komentarz, t. I, red. L. Garlicki, M. Zubik, Warszawa 2016,

14 B. Banaszak, Konstytucja Rzeczypospolitej Polskiej. Komentarz, Warszawa 2012.

15 W. Komarnicki, Polskie prawo polityczne, Warszawa 1922, s. 212.

16 Ibidem, s. 215.

17 Ibidem.

18 L. Peiper, Kodeks karny i prawo o wykroczeniach, Kraków 1933, s. 434. 
zależnie od odczuć samego pokrzywdzonego ${ }^{19}$. W literaturze jako bezpośrednie dobro chronione wskazuje się: godność, szacunek dla Narodu i Rzeczypospolitej Polskiej ${ }^{20}$, cześć i szacunek należne Narodowi oraz Rzeczypospolitej Polskiej ${ }^{21}$, cześć, powszechny szacunek ${ }^{22}$, cześć oraz powszechny szacunek, jakim powinny być otoczone RP oraz naród polski ${ }^{23}$. Nieco inaczej ujmuje się dobro chronione w komentarzu do Kodeksu karnego pod red. M. Mozgawy, wskazując, że głównym dobrem chronionym jest: dobre imię oraz godność Narodu Polskiego i Rzeczypospolitej Polskiej. Ubocznym przedmiotem ochrony jest poczucie godności osób narodowości polskiej i obywateli polskich ${ }^{24}$. W Kodeksie karnym z 1932 r. znieważenie miało postać normatywną przestępstwa obrazy, co - jak tłumaczył J. Makarewicz - oznaczało, że dobrem chronionym było poczucie własnej godności, której nie można odmówić nikomu ${ }^{25}$.

Czynność sprawcza wyraźnie określona została przez ustawodawcę w art. 133 k.k. jako „znieważanie”. Pojęcie to jest użyte m.in. także w art. 216 k.k., stanowiąc ustawowe znamię przestępstwa znieważenia, a także np. w art. 135 $\$ 2$ k.k. w przestępstwie znieważenia Prezydenta RP, oraz w przestępstwach znieważenia godła, sztandaru, chorągwi, bandery, flagi lub innego znaku państwowego (art. 137 \$ 1 i $\$ 2$ k.k.), znieważenia funkcjonariusza publicznego (226 k.k.). W ramach niesprzeczności wewnętrznej jednego i tego samego aktu normatywnego czasownikowe znamię „znieważa” powinno mieć taką samą treść we wszystkich typach rodzajowych, w których czynność sprawcza polega na znieważeniu, a przepisy chronią takie samo dobro prawne - cześć człowieka, czyli godność wewnętrzną, więc przekonanie o własnej wartości, a, co więcej, z tego właśnie powodu wszystkie te typy rodzajowe stanowić będą przestępstwa podobne ${ }^{26}$. W judykaturze znieważenie na gruncie art. 216 k.k. jest rozumiane jako: wszelkie zachowania sprawcy, które w sposób demonstracyjny wyrażaja pogardę dla innej osoby, w szczególności maja poniżyć jego godność osobistą i sprawić, by poczut się dotknięty lub obrażony ${ }^{27}$. W piśmiennictwie zniewaga ogólnie określona jako czynność sprawcza w kontekście tego przepisu jest tłumaczona często przez podawanie rozmaitych postaci zachowania znieważającego, np. znieważa-

19 W. Kulesza, Zniesławienie i zniewaga (Ochrona czci i godności osobistej człowieka w polskim prawie karnym - Zagadnienia podstawowe), Warszawa 1984, s. 169.

20 J. Kulesza [w:] Kodeks karny, red. M. Królikowski, R. Zawłocki, op. cit., s. 122.

21 J. Giezek, Kodeks karny, op. cit.

22 J. Wojciechowska [w:] Kodeks karny. Komentarz, red. A. Wąsek, Warszawa 2008, s. 84.

23 S. Hoc [w:] System prawa karnego, t. 8, red. L. Gardocki, Warszawa 2012.

24 M. Budyn-Kulig [w:] Kodeks karny. Komentarz aktualizowany, red. M. Mozgawa, 2017, LEX.

25 J. Makarewicz, Kodeks karny z komentarzem, op. cit., s. 582.

26 M. Gałązka [w:] Kodeks karny. Komentarz, red. A. Grześkowiak, K. Wiak, Warszawa 2018, s. 734.

27 Postanowienie SN z 7 maja 2008 r., sygn. akt III KK 234/07. 
niem jest użycie słów pogardliwie, wulgarnie określających przedmiot czynności wykonawczej, epitetów, inwektyw, wyzwisk i słów powszechnie uznanych za obraźliwe, obelżywe, poniżające. To uwłaczanie, ubliżanie, lżenie, bezczeszczenie, pohańbienie, wyszydzanie, zohydzanie, upokarzanie, wystawianie na pośmiewisko, zachowanie, które wyraża pogardę ${ }^{28}$. Uogólniając, przyjmuje się, że chodzi o różne zachowania wyrażające pogardę dla godności drugiego człowieka ${ }^{29}$.

Tak też rozumiano to pojęcie na tle Kodeksu karnego z 1932 r. S. Glaser uważał za znieważenie naruszenie poczucia godności osobistej, okazanie pogardy drugiej osobie ${ }^{30}$. Natomiast na tle art. 152 k.k. z 1932 r., chroniącego Naród Polski i Państwo Polskie przed lżeniem i wyszydzaniem, J. Makarewicz wskazywał, że: pojęcia w nim użyte sa różne od wyrażenia „znieważa”, gdyż znieważenie odpowiada wyrażeniu pogardy czy lekceważenia $w$ formie szczególnie brutalnej (...) natomiast w pojęciu „lżenia” $i$ „wyszydzania” tkwi czynnik użycia słów lub gestów zawierających $w$ sobie, poza osobista pogarda i lekceważeniem, myśl wystawienia na pośmiewisko powszechne ${ }^{31}$.

Kwestię znieważenia m.in. na tle art. 133 k.k. podjął Trybunał Konstytucyjny, odnotowując w cytowanym wcześniej wyroku z 21 września 2015 r. o sygn. akt $\mathrm{K} 28 / 13$, że to pojęcie nie zostało zdefiniowane przez ustawodawcę. Stąd uznał za konieczne określenie jego treści. Wskazując na różne słownikowe znaczenia pojęcia znieważenia, zatrzymał się na jego współczesnym znaczeniu, wskazując, że: według słownika „znieważać” to „ubliżyć (ublizać) komuś, zachować się (zachowywać się) względem kogoś w sposób obraźliwy, zelizyć (lizyć), obrazić (obrażać)”, a „poniżyć” to „obrazić (obrażać) czyjąś godność, upokorzyć (upokarzać) kogoś. Przyjął, że: „znieważanie” można uznać za równoznaczne z obrażaniem albo z wynikającym z pogardy lżeniem lub zniesławianiem, „poniżanie” zaś sprowadza się do upokarzania czy też uwłaczania godności.

Okolicznością modalną czynu w typie przestępstwa znieważenia Narodu lub Rzeczypospolitej Polskiej z art. 133 k.k. jest znamię sytuacyjne „publicznie”, co oznacza, że czynność sprawcza musi być dokonana publicznie. Na ogół zarówno w piśmiennictwie, jak i w judykaturze przyjmuje się, że działanie publiczne zachodzi, gdy może być dostrzeżone przez bliżej nieokreśloną liczbę osób lub gdy następuje w miejscu dostępnym dla bliżej nieoznaczonej liczby osób, czego sprawca powinien mieć świadomość. Ta okoliczność jest jednak w części doktryny kwestionowana ${ }^{32}$.

28 J. Kulesza [w:] Kodeks karny, red. M. Królikowski, R. Zawłocki, op. cit., s. 123; idem [w:] System prawa karnego, t. 10, red. J. Warylewski, Warszawa 2012, s. 1081, 1085.

29 J. Raglewski [w:] Kodeks karny. Część szczególna, red. A. Zoll, Warszawa 2013, s. 835.

30 S. Glaser, Polskie prawo karne w zarysie, Kraków 1933, s. 326.

31 J. Makarewicz, Kodeks karny z komentarzem, op. cit., s. 402.

32 P. Kardas, Kodeks karny. Część szczególna, op. cit., s. 125. 
Dla podstawowego problemu, określonego tytułem tego opracowania, istotne znaczenie ma też wskazanie, że przestępstwo z art. 133 k.k. jest umyślnym czynem zabronionym. Może być popełnione wyłącznie z zamiarem bezpośrednim, a zatem niezbędne jest wystąpienie tzw. animus iniurandi. Jednak w doktrynie można spotkać pogląd odmienny, według którego możliwe jest popełnienie tego przestępstwa także z zamiarem ewentualnym ${ }^{33}$.

2. Wprowadzony do tekstu ustawy z $1998 \mathrm{r}$. o IPN przepis art. $55 \mathrm{w}$ projekcie ustawy umieszczony w art. 49, miał treść: Kto publicznie i wbrew faktom zaprzecza nazistowskim lub komunistycznym zbrodniom, o których mowa $w$ art. 1 pkt 1 lit. a, podlega grzywnie. Po pracach legislacyjnych przepisowi temu, zamieszczonemu w art. 55 ustawy o IPN, nadano treść: Kto publicznie i wbrew faktom zaprzecza zbrodniom, o których mowa $w$ art. 1 pkt 1, podlega grzywnie lub karze pozbawienia wolności do lat 3. Wyrok podawany jest do wiadomości publicznej. $\mathrm{W}$ tej treści przetrwał on do chwili obecnej. W języku potocznym znany jest pod nazwą kłamstwa oświęcimskiego.

Dobro chronione tym przepisem może być zrekonstruowane z preambuły do tej ustawy, w której w punkcie 1 ustawodawca eksponuje, jako jeden z motywów jej uchwalenia, zachowanie pamięci o ogromie ofiar, strat i szkód poniesionych przez Naród Polski w latach II wojny światowej i po jej zakończeniu. Wskazuje się w literaturze, idąc za poglądem W. Kuleszy, że dobrem chronionym w art. 55 ustawy o IPN jest pamięć zbiorowa, będąca elementem godności człowieka ${ }^{34}$. Podobnie ujmują problem dobra chronionego A. Janisławski i P. Konopka, uznając, że jest nim ochrona pamięci o ofiarach zbrodni ludobójstwa, podkreślają, że ustawodawca przez wprowadzenie przepisu art. 55 tej ustawy chce chronić pamięć i godność niezliczonej liczby osób pomordowanych i prześladowanych ${ }^{35}$. Zupełnie inaczej przedstawiał kwestię dobra chronionego tym przepisem Rzecznik Praw Obywatelskich, który we wniosku z 19 września 2008 r. zaskarżył do Trybunału Konstytucyjnego przepis art. 55 ustawy o IPN, zarzucając jego niezgodność z przepisami Konstytucji RP. We wniosku suponował, że powodem wprowadzenia do porządku prawnego art. 55 ustawy o IPN przez ustawodawcę była chęć uczynienia przedmiotem ochrony: prawdy historycznej o zbrodniach systemów totalitarnych XX wieku, pamięci o ofiarach narodowo-socjalistycznego ludobójstwa oraz demokratycznego ustroju państwa, jak również bezpieczeństwa i moralności publicznej, co krytykował, uważając, że: zadanie ustalania prawdy

33 J. Wojciechowska [w:] Kodeks karny, op. cit., s. 85; I. Zgoliński [w:] Kodeks karny. Komentarz, red. V. Konarska-Wrzosek, 2017, LEX.

34 W. Kulesza, Wadliwe kody pamięci a zbiorowa pamięć jako dobro społeczne chronione prawem [w:] Wadliwe kody pamięci. Zniekształcenia pamięci o zbrodniach międzynarodowych $w$ dyskursie publicznym, red. A. Nowak-Far, Ł. Zamęcki, Warszawa 2015, s. 164 i n.

35 A. Janisławski, P. Konopka, Zagadnienie penalizacji „kłamstwa oświęcimskiego”, „Palestra” 2009, nr 1-2, s. 53. 
historycznej nie należy do prawodawcy, ale do przedstawicieli nauki. Domagał się przy tym depenalizacji zachowania opisanego w art. 55 ustawy o IPN ${ }^{36}$.

Czynność sprawcza została w art. 55 ustawy o IPN określona w sposób wyraźny, niebudzący wątpliwości. Ustawodawca określił ją, używając zwrotu „zaprzecza”. Zachowanie sprawcy czynu zabronionego polega na zaprzeczaniu, czyli negowaniu zbrodni, o których mowa w art. 1 pkt 1 tej ustawy. W języku polskim zwrot ten ma ściśle określone znaczenie. Słownik języka polskiego wskazuje, że: zaprzeczać to zakwestionować prawdziwość czegoś, pozostać w sprzeczności z czymś, nie uznać czegoś ${ }^{37}$. Zaprzeczanie to inaczej zanegowanie, stąd przestępstwo zaprzeczania zbrodniom $\mathrm{z}$ art. 1 pkt 1 ustawy o IPN nazywane jest przestępstwem negacjonizmu. W przepisie art. 55 tej ustawy sprawca zaprzecza zbrodniom nazistowskim i komunistycznym popełnionym na osobach narodowości polskiej lub obywatelach polskich innych narodowości w okresie od dnia 8 listopada 1917 r. do dnia 31 lipca 1990 r. lub zaprzecza innym przestępstwom stanowiącym zbrodnie przeciwko pokojowi, ludzkości lub zbrodnie wojenne. Nie uznaje zatem, że czyny takie były zbrodniami wskazanymi w art. 1 pkt 1 ustawy o IPN, wypowiadając pogląd negujący te zbrodnie. Pojęcie „zaprzecza”, będące ustawowym znamieniem czynnościowym przestępstwa z art. 55 ustawy o IPN, występuje również w wypowiedziach Rady Europy i Unii Europejskiej oraz wielu ustawach penalizujących podobne zachowania ${ }^{38}$. Tak więc na podstawie art. 55 ustawy o IPN karalny jest jedynie sam fakt publicznego zaprzeczania - wbrew faktom - zbrodniom dokonanym przez nazistów, komunistów, jak również innym przestępstwom stanowiącym zbrodnie przeciwko pokojowi, ludzkości lub zaprzeczania zbrodniom wojennym, o których mowa w art. 1 pkt 1 ustawy o IPN.

Do strony przedmiotowej przestępstwa z art. 55 ustawy o IPN należą również okoliczności modalne czynu. Stanowią je dwie okoliczności - „publicznie” i „wbrew faktom”, zaprzeczenie określonym zbrodniom powinno być „publiczne” oraz dokonane „wbrew faktom”.

Pierwsza z tych okoliczności została skrótowo przeanalizowana przy omówieniu art. 133 k.k. Ustawowe znamię „publiczności” ma identyczną treść i w normatywnym opisie czynu zabronionego $z$ art. 55 ustawy o IPN.

Okolicznością o charakterze przedmiotowym jest ponadto ustawowe znamię nakreślające w wyznaczonym zakresie granicę penalizacji. Zaprzeczanie zbrodniom musi nastąpić „wbrew faktom”. Pojęcie „fakt” jest istotne w zespole ustawowych znamion czynu z art. 55 ustawy o IPN. W znaczeniu słownikowym: fakt to to, co zaszło lub zachodzi $w$ rzeczywistości $i^{39}$. Fakt w sensie użytym w analizowanym przepisie to wydarzenie historyczne, wydarzenie z przeszłości, które w rze-

\footnotetext{
36 Postanowienie TK z 8 marca 2011 r., sygn. akt K 29/08.

37 Https://sjp.pwn.pl/szukaj/zaprzecza\%C4\%87.html.

38 A. Janisławski, P. Konopka, Zagadnienie penalizacji, op. cit., s. 58-62.

39 Https://sjp.pwn.pl/szukaj/fakt.html.
} 
czywistości miało miejsce, a więc zdarzenie zaistniałe, takie, którego istnienie zostało ustalone i stwierdzone jako pewne i nie budzi wątpliwości. Istotę faktu oddaje popularne powiedzenie, że „z faktami się nie dyskutuje”, gdyż one wystąpiły w rzeczywistości. Jeżeli fakt został stwierdzony - to znaczy, że wydarzenie miało miejsce, co zostało ustalone ponad wszelką wątpliwość.

W kontekście przedmiotu czynności wykonawczej chodzi więc o takie zbrodnie, których zaistnienie zostało stwierdzone, stanowią one fakt oczywisty, gdyż są zgodne z rzeczywistością i zostały potwierdzone wynikami badań historycznych. Sprawca jednak temu zaprzecza, a więc je neguje, czym wyczerpuje ustawowe znamiona strony przedmiotowej tego typu przestępstwa. Jak wyjaśniał W. Hajduk, podsekretarz stanu w Ministerstwie Sprawiedliwości, w odpowiedzi na interpelację z dn. 27 lutego 2014 r.: Na podstawie rzeczonej normy karalny jest jedynie sam fakt publicznego zaprzeczania - wbrew faktom - zbrodniom dokonanym przez nazistów, komunistów, jak również innym przestępstwom stanowiącym zbrodnie przeciwko pokojowi, ludzkości lub zaprzeczania zbrodniom wojennym (o których mowa w art. 1 pkt 1 ustawy o IPN $)^{40}$.

Przestępstwo z art. 55 ustawy o IPN jest przestępstwem formalnym. Przedmiotową podstawą odpowiedzialności jest samo zachowanie polegające na zaprzeczeniu określonym w przepisie zbrodniom.

Odpowiedzialność karna za przestępstwo z art. 55 ustawy o IPN zależeć będzie również od wyczerpania ustawowego znamienia strony podmiotowej, a zatem sprawca przestępstwa $\mathrm{z}$ art. 55 ustawy o IPN musi dopuścić się zaprzeczenia zbrodniom umyślnie. Należy przyjąć, że przestępstwo to może być popełnione z zamiarem bezpośrednim lub ewentualnym. Sprawca musi więc mieć świadomość tego, że wypowiedzią swoją publicznie zaprzecza ustalonym faktom. Jeżeli zachowanie sprawcy cechuje zamiar bezpośredni, sprawca, działając świadomie, chce im zaprzeczyć. Wydaje się, że czyn może być popełniony również w zamiarze ewentualnym, gdy sprawca przewiduje możliwość popełnienia tego czynu a zatem ma świadomość tego, że publicznie zaprzecza faktom - i na to się godzi.

Rzecznik Praw Obywatelskich uznał penalizację zachowania opisanego w art. 55 ustawy o IPN za zbędną, wywodząc, że ochrona prawna demokratycznego ustroju państwa oraz bezpieczeństwa, porządku i moralności publicznej przed wskazanymi wyżej zachowaniami jest realizowana m.in. na podstawie przepisów Kodeksu karnego, w szczególności jego art. 256 oraz art. 257, penalizujących propagowanie faszyzmu i totalitaryzmu oraz znieważanie grupy osób lub poszczególnej osoby, i że przepisy te zabezpieczą ochronę prawną dóbr chronionych przez art. 55 ustawy o IPN. Domagał się depenalizacji „kłamstwa oświęcimskiego". Jednak pismem z 22 lutego 2011 r. wycofał w całości wniosek z 19 września 2008 r.

40 Http://www.sejm.gov.pl/sejm7.nsf/InterpelacjaTresc.xsp?key=1670D8D8. 
3. Ustawą z 26 stycznia 2018 r. wprowadzony został do rozdziału 7 ustawy o IPN, zawierającego przepisy o charakterze prawnokarnym, przepis art. 55a, penalizujący zachowanie polegające na publicznym i wbrew faktom przypisywaniu Narodowi Polskiemu lub Państwu Polskiemu odpowiedzialności lub współodpowiedzialności za popełnione przez III Rzeszę Niemiecką zbrodnie nazistowskie określone w art. 6 Karty Międzynarodowego Trybunału Wojskowego załączonej do Porozumienia międzynarodowego w przedmiocie ścigania i karania głównych przestępców wojennych Osi Europejskiej, podpisanego w Londynie 8 sierpnia 1945 r., lub za inne przestępstwa stanowiące zbrodnie przeciwko pokojowi, ludzkości lub zbrodnie wojenne lub w inny sposób rażącym pomniejszaniu odpowiedzialności rzeczywistych sprawców tych zbrodni. Czyn taki zagrożony jest grzywną lub karą pozbawienia wolności do lat 3, obok kary obligatoryjnie orzeka się środek karny w postaci podania wyroku do wiadomości publicznej.

Dla lepszego zrozumienia motywów, którymi kierował się ustawodawca, wprowadzając do polskiego ustawodawstwa przepis o tej treści, zasadne będzie przedstawienie jego dość znamiennej historii i trudnej drogi legislacyjnej. Wywodzi on się z art. $45^{1}$ poselskiego projektu zmiany ustawy o Instytucie Pamięci Narodowej z 2 lutego 2006 r. o treści: Instytut Pamięci z urzędu wszczyna postępowanie w sprawie pomówienia Narodu lub Państwa Polskiego, grupy polskich obywateli lub też osób indywidualnych będących obywatelami polskimi o udział, organizowanie lub odpowiedzialność za zbrodnie komunistyczne i nazistowskie ${ }^{41}$. W wyniku uzgodnień z legislatorami i ekspertami zaproponowano w komisji sejmowej rozpatrującej ten projekt, by do ustawy o IPN dodać m.in. przepis art. 55a, który miałby brzmienie: Kto publicznie pomawia Naród Polski o udział, organizowanie lub odpowiedzialność za zbrodnie komunistyczne lub nazistowskie podlega karze pozbawienia wolności do lat trzech. Przepis ten został uchwalony przez Sejm. Jednak Senat w ramach poprawek wykreślił go z ustawy o IPN, a w jego miejsce zaproponował wprowadzenie do Kodeksu karnego przepisu art. 132a o identycznej treści jak wykreślony art. 55a ustawy o IPN. Sejm tę poprawkę przyjął i w konsekwencji ustawą z 18 października 2006 r. o ujawnianiu informacji o dokumentach organów bezpieczeństwa państwa z lat 1944-1990 oraz treści tych dokumentów dodano art. 132a do Kodeksu karnego. Przepis ten nie obowiązywał długo, ponieważ został przez Rzecznika Praw Obywatelskich zaskarżony do Trybunału Konstytucyjnego. Trybunał Konstytucyjny wyrokiem z 19 września 2008 r., sygn. akt K 5/07, uznał go za niezgodny z Konstytucją RP $\mathrm{z}$ uwagi na nieprawidłowość procesu legislacyjnego.

Po raz kolejny zaproponowano wprowadzenie do prawa karnego dwóch przepisów o treści mniej więcej odpowiadającej brzmieniu obecnego przepisu art. 55a ustawy o IPN w poselskim projekcie ustawy o zmianie ustawy o IPN

${ }^{41}$ Druk sejmowy nr 344/V kad. 
i in. ustaw z 15 października $2013 \mathrm{r}^{42}$. Projektowane przepisy miały otrzymać brzmienie: Art. 55a. Kto publicznie oskarża o udział w masowych zbrodniach polskie, niepodległościowe, niekomunistyczne, podziemne formacje i organizacje Polskiego Państwa Podziemnego, podlega grzywnie, ograniczeniu wolności lub karze pozbawienia wolności do lat 5. Wyrok podawany jest do publicznej wiadomości; art. 55b. Kto publicznie używa słów „polskie obozy śmierci”, „polskie obozy zagła$d y$ ", "polskie obozy koncentracyjne" lub innych, które stosuja przymiotnik "polskie” wobec niemieckich nazistowskich obozów koncentracyjnych i ośrodków zagłady, podlega grzywnie, ograniczeniu wolności lub karze pozbawienia wolności do lat 5. Wyrok podawany jest do publicznej wiadomości.

Do projektu dołączone było uzasadnienie wskazujące na pilną potrzebę wprowadzenia takiej regulacji do polskiego systemu prawa. Konieczność prawnokarnej ochrony dobrego imienia Rzeczypospolitej Polskiej racjonalizowano pojawianiem się od wielu lat w obiegu publicznym, w tym także za granicą, takich określeń, jak „polskie obozy śmierci”, „polskie obozy zagłady”, „polskie obozy koncentracyjne”. Zdarza się, że takich określeń wielokrotnie używaja te same osoby lub tytuły prasowe czy stacje telewizyjne lub radiowe. Pojawiaja się także wydawnictwa, programy, które świadomie fałszuja historię, zwłaszcza najnowsza, pokazując Polskie Państwo Podziemne z okresu II wojny światowej czy wręcz wszystkich Polaków, jako zbrodniarzy czy antysemitów $w^{43}$. W uzasadnieniu projektu zmian ustawy o IPN wskazywano, że ponieważ dotychczasowe przeciwdziałania prezentacji takich twierdzeń szkalujących Polskę i Polaków nie przynoszą rezultatów, zdecydowano się w przeciwdziałanie włączyć prawo karne, wprowadzając zakaz takich zachowań pod groźbą kary. Równocześnie tłumaczono, że przepisy o podobnej treści, zwłaszcza penalizujące tzw. kłamstwo oświęcimskie wprowadzono już do krajowego prawa w wielu państwach, jako wzór skutecznych działań prawnych wskazując państwo Izrael. Projektodawcy uznali, że: potrzebna jest wytrwała i konsekwentna polityka historyczna polskich władz. Potrzebne sa jednak do tego także skuteczne narzędzia prawne, które taka polityke pozwola prowadzić. Dlatego też proponowane zmiany prawa powinny jak najszybciej zaczać funkcjonować, by polski rząd mógt w końcu podjąć skuteczne działania $w$ obronie polskiego interesu narodowego ${ }^{44}$. W opiniach zewnętrznych zleconych przez BAS, wskazywano na celowość, wręcz konieczność, wprowadzenia: instrumentarium prawno-karnego dla zwalczania zjawisk szkodzacych Państwu Polskiemu i jego obywatelom na tle autentycznych potrzeb faktycznych $w$ tym względzie i, co również jest istotne, przyznawano, że: zabezpieczenie dóbr prawem chronionych $z$ art. 55a i 55b Projektu nie jest możliwe za pomoca innych instrumentów prawnych aniżeli z zakresu prawa karnego, w szczególności niewy-

42 Druk sejmowy nr 1958/VII kad.

43 Ibidem, uzasadnienie.

44 Ibidem. 
starczajace sq instrumenty cywilno-prawne $i$ dyplomatyczne ${ }^{45}$. Jednak pomimo pozytywnie ocenionej intencji proponowanej ustawy oraz uznania konieczności wprowadzenia prawnokarnej ochrony Państwa Polskiego i jego obywateli przed szkodami wyrządzanymi kryminalizowanymi w tych przepisach zachowaniami i podkreślenia, że: edukacja historyczna sama $w$ sobie nie jest zdolna do zabezpieczenia pamięci i godności ofiar totalizmów, projektowane przepisy zostały zaopiniowane negatywnie $\mathrm{z}$ uwagi na zastrzeżenia natury konstytucyjnej oraz sposób ujęcia niektórych ustawowych znamion proponowanych czynów zabronionych. W części podobne zastrzeżenia co do niedookreśloności niektórych ustawowych znamion zawartych w proponowanym art. 55a ustawy i ich sprzeczności z zasadą nullum crimen sine lege zgłoszone zostały i w drugiej opinii, w której jednak uznano za poprawne ujęcia drugiego proponowanego przepisu ${ }^{46}$.

Opinię do tego projektu przesłała również Krajowa Rada Sądownictwa, podzielając intencje projektodawców co do konieczności ścigania zachowań stypizowanych w projektowanych przepisach art. 55a i 55b ustawy o IPN, wskazała jednak, że: istniejący porządek prawny umożliwia w pełni penalizacje czynów polegajacych na publicznym oskarżaniu polskich niekomunistycznych formacji niepodległościowych o udział w masowych zbrodniach jak i publicznym wyrażaniu słów "polskie obozy śmierci" i tym podobnych wobec niemieckich nazistowskich obozów koncentracyjnych i ośrodków zagłady. Zachowania takie wyczerpują bowiem znamiona przestępstwa określonego $w$ art. 133 kk polegajacego na publicznym znieważaniu Narodu lub Rzeczypospolitej Polskiej. Proponowana penalizację zachowań uznano za $z b e ̨ d n a^{47}$. Przeciwny uchwaleniu proponowanych art. 55a i 55b ustawy o IPN był także rząd - w opinii do tego projektu wskazano, że budzi on wątpliwości zarówno natury konstytucyjnej, jak i prawnokarnej, zwłaszcza wskazując na niezgodność opisu normatywnego przestępstw z zasadą nullum crimen sine lege certa. I w tym wypadku jednak aprobowano intencje projektowanej ustawy ${ }^{48}$. Podobnie wywodził w opinii Prokurator Generalny, negatywnie opiniując projekt ustawy. Natomiast Prezes Sądu Najwyższego w piśmie z 20 listopada 2013 r. uznał za niecelowe opiniowanie poselskiego projektu ustawy w powołaniu się na art. 1 pkt 3 ustawy o SN z 23 listopada 2002 r. Proces legislacyjny zakończył się na pierwszym czytaniu projektu ustawy.

45 M. Filar, M. Berent, Opinia prawna w przedmiocie poselskiego projektu ustawy o zmianie ustawy o Instytucie Pamięci Narodowej - Komisji Ścigania Zbrodni przeciwko Narodowi Polskiemu oraz ustawy - Kodeks karny (druk nr 1958), 4 lutego 2014 r., http:// orka.sejm.gov.pl/rexdomk7.nsf/Opdodr?OpenPage\&nr=1958.

46 A. Bojańczyk, Opinia prawna na temat poselskiego projektu ustawy o zmianie ustawy o Instytucie Pamięci Narodowej - Komisji Ścigania Zbrodni Przeciwko Narodowi Polskiemu oraz ustawy - Kodeks karny (druk sejmowy 1958), 30 stycznia 2014 r.

47 Opinia KRS z 6 grudnia 2013 r. w przedmiocie projektu ustawy o zmianie ustawy o IPN-KŚZpNP oraz ustawy Kodeks karny do druku sejmowego nr 1958/VII kad.

48 Stanowisko Rządu RP z 31 marca 2014 r., druk sejmowy nr 1958/VII kad. 
Problem podjęto na nowo w 2016 r., po wpłynięciu do Sejmu rządowego projektu ustawy o zmianie ustawy o IPN i innych ustaw z 29 sierpnia 2016 r. $^{49}$. Zaproponowano w nim dodanie do tej ustawy odrębnego rozdziału $6 \mathrm{c}$ zatytułowanego „Ochrona dobrego imienia Rzeczypospolitej Polskiej i Narodu Polskiego", w którym ujęty został przepis art. 55a o charakterze prawnokarnym. Jego treść tylko w części nawiązywała do ustawowych znamion przestępstwa zamieszczanego we wcześniejszych jego projektach. Penalizacji miało ulec zachowanie polegające na publicznym i wbrew faktom przypisywaniu Narodowi Polskiemu lub Państwu Polskiemu odpowiedzialności lub współodpowiedzialności za popełnione przez III Rzeszę Niemiecką zbrodnie nazistowskie określone w art. 6 Karty Międzynarodowego Trybunału Wojskowego załączonej do Porozumienia międzynarodowego w przedmiocie ścigania i karania głównych przestępców wojennych Osi Europejskiej, podpisanego w Londynie 8 sierpnia 1945 r., lub za inne przestępstwa stanowiące zbrodnie przeciwko pokojowi, ludzkości lub zbrodnie wojenne lub w inny sposób rażące pomniejszanie odpowiedzialności rzeczywistych sprawców tych zbrodni. Przestępstwo zagrożone byłoby grzywną lub karą pozbawienia wolności do lat 3 , a wyrok miałby być podawany do publicznej wiadomości. Przewidziano również odpowiedzialność karną za nieumyślne popełnienie czynu zabronionego oraz kontratyp polegający na umyślnym lub nieumyślnym dopuszczeniu się czynu $\mathrm{w}$ ramach działalności artystycznej lub naukowej. W szerokim uzasadnieniu projektodawcy wskazali na wiele aspektów propozycji prawnokarnej ochrony dobrego imienia Narodu i Państwa Polskiego. I, co istotne, podkreślili konieczność stworzenia: skutecznych narzędzi prawnych pozwalajacych prowadzić wytrwała i konsekwentna politykę historyczna polskich władz w zakresie przeciwdziałania fałszowaniu polskiej historii i ochrony dobrego imienia Rzeczypospolitej Polskiej i Narodu Polskiego ${ }^{50}$. Jeszcze na etapie rządowych prac nad projektem ustawy o zmianie ustawy o IPN Prezes IPN pismem z 25 lutego $2016 \mathrm{r}$. zaproponował zmianę treści projektowanego przepisu art. 55a ustawy na zapis: Kto publicznie i wbrew faktom w celu poniżenia Rzeczypospolitej Polskiej lub Narodu Polskiego przypisuje Narodowi Polskiemu udział, organizowanie, odpowiedzialność lub współodpowiedzialność za popetnienie przez III Rzeszę Niemiecka zbrodni przeciwko pokojowi, ludzkości lub zbrodni wojennych, podlega karze pozbawienia wolności do lat 5. Wyrok podawany jest do publicznej wiadomości $i^{51}$. Propozycja ta nie została uwzględniona. W toku prac legislacyjnych prowadzonych w Sejmie treść proponowanego w projekcie $\mathrm{z}$ druku sejmowego nr 806 przepisu art. 55a ustawy o IPN nie uległa większej zmianie. $Z$ uwagi na to, że Senat nie wniósł do ustawy poprawek, tekst w brzmieniu uchwalonym przez

49 Druk sejmowy nr 806/VIII kad.

50 Druk sejmowy nr 806/VIII kad., uzasadnienie.

51 Pismo Prezesa IPN z 25 lutego 2016 r. 
Sejm, po podpisaniu go przez Prezydenta RP został ogłoszony w Dzienniku Ustaw pod poz. 369.

Analiza ustawowych znamion przestępstwa $\mathrm{z}$ art. 55a ustawy o IPN jest w pewnym sensie ułatwiona, gdyż przepis zawiera niektóre ze znamion występujących w art. 133 k.k. lub art. 55 ustawy o IPN, omówionych wyżej. Oczywiście nie chodzi o ustawowe znamiona określające zachowanie sprawcy, ale np. o przedmiot czynności wykonawczej, którym jest Naród Polski lub Państwo Polskie, albo modalną okoliczność polegającą na publiczności zachowania, lub wskazaniu, że sprawca stawia zarzut wbrew faktom.

Dobro chronione przepisem art. 55a ustawy o IPN, umieszczonym w jej rozdziale 7, zawierającym przepisy karne, pokrywa się z dobrem wskazanym w tytule rozdziału $6 c$ tej ustawy, dotyczącym jego cywilnoprawnej ochrony. Jest ono więc wspólne dla ochrony cywilnoprawnej oraz karnej. Jest nim dobre imię Rzeczypospolitej Polskiej i Narodu Polskiego, czyli godność narodowa i państwowa. Dobre imię jest bowiem składnikiem godności, a bardziej szczegółowo jest - jak pisze W. Kulesza - substratem czci $^{52}$. Cześć to dobro - którego istotą jest ustosunkowanie się do danego podmiotu innych podmiotów. Dobre imię składa się na cześć „zewnętrzną”, poważanie, jakim się cieszy dany podmiot w opinii publicznej. W. Makowski uważał, że chodzi w tym wypadku o objaw, który można nazwać czcią społeczną, czyli jak się mówi potocznie dobrym imieniem ${ }^{53}$, przy czym autor wyjaśniał, że nie chodzi o cześć osobistą ani obywatelską, ale cześć społeczną w rozumieniu oceny w stosunkach społecznych. Na tle przepisu art. 55a ustawy o IPN można zatem stwierdzić, że w grę wchodzi aspekt obiektywny ochrony czci. Należy także przyjąć, że dotyczy to również oceny Państwa Polskiego i Narodu jako szczególnych podmiotów zbiorowych w stosunkach międzynarodowych. Patrząc na tę kwestię z innej strony, należy wskazać, że dobrem chronionym bezpośrednio jest Rzeczpospolita Polska i Naród Polski widziane przez ich pozycję i należną im cześć w sferze publicznej.

Pojęcie Narodu i Państwa Polskiego jako podmiotów, których dobre imię jest chronione przepisem art. 55a ustawy o IPN, jest interpretowane tak jak przy czynie zabronionym z art. 133 k.k., przy czym należy mieć na uwadze różne zakresy treściowe pojęcia „Naród”. Właśnie w kontekście tego przepisu jest wyraźnie widoczny niedostatek interpretacji pojęcia „Naród” wyłącznie na podstawie preambuły Konstytucji RP. Wydaje się szczególnie istotne, by pojęciem „Narodu” objąć nie tylko wszystkich obywateli polskich żyjących w Polsce lub poza jej granicami, ale także osoby pochodzenia polskiego niemające obywatelstwa polskiego, ale mające poczucie tożsamości i kultury narodowej oraz kultywujących więź narodową. Sugestię, by stanowiącym ustawowe znamię czynu zabronionego

\footnotetext{
52 W. Kulesza, Zniesławienie i zniewaga, op. cit., s. 33.

53 W. Makowski, Kodeks karny, op. cit., s. 571, 572.
} 
pojęciem „Naród” obejmować również „osoby narodowości polskiej niebędące obywatelami polskimi" zawiera opinia Ordo Iuris ${ }^{54}$.

Strona przedmiotowa przestępstwa opisanego w art. 55a ustawy o IPN obejmuje dwie postacie czynności sprawczej. Pierwsza z nich polega na przypisywaniu Narodowi Polskiemu lub Państwu Polskiemu odpowiedzialności lub współodpowiedzialności za określone w przepisie zbrodnie. W tej postaci czynności sprawczej ustawodawca wyodrębnił dwie kategorie zbrodni przypisywanych przez sprawcę Państwu Polskiemu lub Polskiemu Narodowi. W pierwszym rzędzie chodzi o przypisanie zbrodni nazistowskich popełnionych przez III Rzeszę Niemiecką, określonych w art. 6 Karty Międzynarodowego Trybunału Wojskowego utworzonego na podstawie Porozumienia międzynarodowego $\mathrm{w}$ przedmiocie ścigania i karania głównych przestępców wojennych Osi Europejskiej, podpisanego w Londynie 8 sierpnia $1945 \mathrm{r}$. Wskazany przepis wymienia: zbrodnie przeciwko pokojowi, zbrodnie wojenne i zbrodnie przeciwko ludzkości, szeroko określając ich postacie. Druga kategoria przestępstw, przypisywanie których Narodowi Polskiemu lub Państwu Polskiemu daje przedmiotowe podstawy do odpowiedzialności karnej, nie została ściśle określona - obejmuje ona inne niż wskazane wyżej zbrodnie nazistowskie, ale takie, które także stanowią zbrodnie przeciwko pokojowi, ludzkości lub zbrodnie wojenne.

Czynność sprawcza zawiera się w „przypisaniu”. Przypisanie w języku polskim oznacza: ustanowić zwiąek kogoś z czymślub uznać, że coś jest przyczyną czegos ${ }^{55}$, jego synonimem jest np. zwrot „obarczyć”, „obciążyć”. Sprawca czynu z art. 55a ustawy o IPN przypisuje Narodowi lub Państwu Polskiemu odpowiedzialność za zbrodnie określone w przepisie. Obarcza te podmioty odpowiedzialnością lub współodpowiedzialnością za zbrodnie nazistowskie popełnione przez III Rzeszę określone w art. 6 Karty Międzynarodowego Trybunału Wojskowego lub za inne przestępstwa stanowiące zbrodnie przeciwko pokojowi, ludzkości lub zbrodnie wojenne. Twierdzi więc, że autorem tych zbrodni był Naród Polski, a zatem określona zbiorowość stanowiąca całość lub Państwo Polskie też pojmowane jako zorganizowana całość. Stawia konkretny, poważny i zniesławiający zarzut, zaliczając Naród Polski i Państwo Polskie do sprawców najcięższych zbrodni. Pomawia zatem wskazane podmioty o postępowanie nielicujące z godnością Narodu i Rzeczypospolitej. Naruszając ich cześć, godzi w dobre imię Narodu Polskiego i Państwa Polskiego, gdyż przedstawia je jako podmioty, na których ciąży popełnienie zbrodni przeciwko pokojowi, ludzkości lub zbrodni wojennych. Przytacza jako prawdziwe pewne, niemające pokrycia w faktach, zdarzenia dotyczące postępowania Narodu Polskiego lub Państwa Polskiego, które wpływają negatywnie na opinię o nich.

54 B. Lewandowski, Analiza art. 55a ustawy o zmianie ustawy o IPN, http://www.ordoiuris.pl/dzialalnosc-instytutu/analiza-art-55a-ustawy-o-zmianie-ustawy-o-ipn.

55 Https://sjp.pwn.pl/sjp/przypisac;2512418.html. 
Drugą postacią czynności sprawczej jest pomniejszanie odpowiedzialności rzeczywistych sprawców zbrodni określonych w przepisie. To pomniejszanie musi dokonywać się w inny sposób niż przez przypisywanie ich Narodowi Polskiemu lub Państwu Polskiemu. Ustawodawca nie określił ściśle tych czynności, tylko zastosował formułę otwartą, która pozwoli na objęcie penalizacją rozmaitych sposobów pomniejszania odpowiedzialności rzeczywistych sprawców tego rodzaju zbrodni. Warunkiem jest, by „pomniejszanie” osiągnęło określony pułap - było rażące. To niedookreślone pojęcie wprowadzone do przepisu art. 55a ustawy o IPN może rodzić problemy interpretacyjne, chociaż w judykaturze nie raz było tłumaczone. Językowo oznacza - rzucające się w oczy, łatwo dostrzegalne, wyraźne i tak pewnie będzie na tle tej ustawy pojmowane.

Przypisanie zbrodni, o których mowa w art. 55a ustawy o IPN Narodowi Polskiemu lub Państwu Polskiemu, i pomniejszanie odpowiedzialności rzeczywistych sprawców zbrodni stanowi pomówienie o takie postępowanie, które może poniżyć wskazane podmioty w opinii publicznej lub narazić je na utratę zaufania. Sprawca podnosi określony zarzut i rozpowszechnia go, na co wskazuje ustawowa sytuacyjna okoliczność modalna czynu - publiczność jego działania. Przestępstwo to czynnościowo koresponduje z przestępstwem zniesławienia określonym w art. 212 k.k. i powinno być interpretowane jako postać zniesławienia. W odniesieniu do przestępstwa z art. 212 k.k. czynność sprawcza polega właśnie na pomawianiu, przez które rozumie się: przypisywanie, zarzucanie, posądzanie lub oskarżanie innej osoby o określone postępowanie lub właściwości, które zawieraja negatywna ocene majaca jednak $w$ konsekwencji prowadzić do poniżenia pomawianego w opinii publicznej lub narazić na utratę zaufania powszechnego ${ }^{56}$. Nie może zatem być wątpliwości, że czyn opisany w art. 55a ustawy o IPN jest szczególną postacią zniesławienia.

Okolicznościami modalnymi dookreślającymi czynność sprawczą są dwa warunki. Pierwszy z nich to wymóg, by sprawca przypisywał publicznie Narodowi Polskiemu lub Państwu Polskiemu zachowania opisane w dyspozycji przepisu. Znamię to występuje zarówno w wyżej omówionym art. 133 k.k., jak i w art. 55 ustawy o IPN w odniesieniu do statuowanych w tych przepisach czynności sprawczych.

Druga okoliczność modalna dookreśla treść zarzutu stawianego przez sprawcę Narodowi Polskiemu lub Państwu Polskiemu. Przypisanie odpowiedzialności czy współodpowiedzialności za zbrodnie określone w art. 55a ustawy o IPN musi być sformułowane wbrew faktom. Wynika stąd wniosek, że zarzut pomawiający ograniczać się powinien tylko do faktów. Wypowiedź zniesławiająca musi zatem mieć charakter wypowiedzi o faktach ${ }^{57}$. Zarzut musi być nieprawdziwy, sprzecz-

56 S. Hypś [w:] Kodeks karny. Komentarz, red. A. Grześkowiak, K. Wiak, Warszawa 2018, s. 1108.

$57 \quad$ Ibidem, s. 1109. 
ny z faktami, czyli z rzeczywistymi zdarzeniami. Na gruncie tej ustawy należy przyjąć, że faktami, o których w niej mowa, są zbrodnie, których zaistnienie na przestrzeni długiego czasu potwierdziły liczne dowody. Właśnie fakty dowodzą, że ani Naród Polski, ani Państwo Polskie nie uczestniczyły w popełnianiu określonych ustawą zbrodni, więc nie można im przypisywać odpowiedzialności lub współodpowiedzialności za ich popełnienie. Pomawianie wbrew ustalonym faktom jest głoszeniem nieprawdy o Narodzie Polskim i Polskim Państwie i tylko takie zachowania są penalizowane art. 55a ustawy o IPN. Znamiona działania "publicznie i wbrew faktom” występują w funkcjonującym od dawna przepisie art. 55 ustawy o IPN w odniesieniu do ujętej w nim czynności sprawczej.

Strona podmiotowa przestępstwa $\mathrm{z}$ art. 55a pkt 1 ustawy o IPN polega na umyślności i to w obu jej postaciach. Może być ono popełnione zarówno z zamiarem bezpośrednim oraz z zamiarem ewentualnym. Elementem obu postaci umyślności jest świadomość, co oznacza, że sprawca musi mieć świadomość co do faktów, ale działa wbrew niej. Ponadto przy zamiarze bezpośrednim musi on chcieć pomówić Naród Polski lub Państwo Polskie, zaś przy zamiarze ewentualnym, przewidując możliwość popełnienia takiego czynu zabronionego, na to się godzić.

Analiza pozostałych punktów art. 55a ustawy o IPN nie jest niezbędna dla ustalenia relacji między przepisami art. 133 k.k., art. 55 ustawy o IPN a art. 55a tejże ustawy.

4. Przepis art. 55a ustawy o IPN wypełnia lukę w prawnokarnej ochronie godności Narodu Polskiego i Państwa Polskiego. Stan prawny w tej materii istniejący przed uchwaleniem przepisu art. 55a ustawy o IPN takiej ochrony nie zapewniał. Co prawda, typy przestępstw zawarte w art. 133 k.k., art. 55 ustawy o IPN oraz art. 55a tej ustawy mają tożsamy ogólny przedmiot ochrony, którym jest suweren - Naród Polski i Rzeczpospolita - Państwo Polskie rozumiane jako dobro wspólne, oraz wspólne rodzajowe dobro, którym jest szeroko rozumiana godność Narodu i Rzeczypospolitej Polskiej. Jednak każdy z tych przepisów chroni inną wartość szczegółową, co oznacza, że różne są w nich bezpośrednie przedmioty ochrony (dobra chronione). Wszystkie trzy przepisy mogłyby być ujęte w ramy jednego rozdziału Kodeksu karnego zatytułowanego „Ochrona godności Narodu Polskiego i Rzeczypospolitej Polskiej”, albo umieszczone w rozdziale XVII k.k. „Przestępstwa przeciwko Rzeczypospolitej Polskiej”, jako grupa typów rodzajowych chroniących godność Narodu Polskiego i Rzeczypospolitej Polskiej. Jednak indywidualne przedmioty ochrony wskazują, że każdy z tych przepisów chroni godność Narodu i Rzeczypospolitej w innym jej aspekcie. W art. 133 k.k. bezpośrednim dobrem chronionym jest cześć i szacunek należny Narodowi Polskiemu i Rzeczypospolitej Polskiej, w art. 55 ustawy o IPN pamięć zbiorowa, będąca składnikiem godności Narodu i Rzeczypospolitej, zaś w art. 55a tej ustawy - dobre imię Narodu Polskiego i Państwa Polskiego. Ta odmienność indywidualnych przedmiotów ochrony prawnokarnej dowodzi, że każdy z nich penali- 
zuje inną przestrzeń rzeczywistości i pełni inne zadania w ramach ochronnych funkcji prawa karnego. Penalizacja ta służy w sumie ochronie autorytetu Narodu Polskiego i Rzeczypospolitej (Państwa Polskiego). Łącznie z innymi jeszcze przepisami Kodeksu karnego, art. 55a ustawy o IPN zapewnia ochronę godności Narodu Polskiego i Rzeczypospolitej Polskiej. W tym zakresie wprowadzenie przepisu art. 55a ustawy o IPN do szeroko pojętego systemu polskiego prawa karnego nie stanowi superfluum konsumowanego przez inne przepisy. Brak tego przepisu powodował, że pewna przestrzeń zamachów na godność Narodu Polskiego i Państwa Polskiego pozostawała dotąd bezkarna.

Odrębność każdego z analizowanych przepisów jest wyraźnie widoczna także przy analizie ustawowych znamion strony przedmiotowej każdego z tych czynów zabronionych. Dotyczy to przede wszystkim czynności sprawczej. Zachowanie sprawcy jest $\mathrm{w}$ każdym $\mathrm{z}$ tych typów odmienne, żadne z nich nie pochłania drugiego i nie może być ze sobą utożsamiane. I tak - w typie rodzajowym zawartym w art. 133 k.k. zachowanie sprawcy polega na znieważeniu, w art. 55 ustawy o IPN sprawca zaprzecza zbrodniom wskazanym w art. 1 pkt 1 ustawy o IPN, zaś w art. 55a tejże ustawy - zachowanie sprawcy stanowi zniesławienie, nie ma cech negowania, ale wręcz odwrotnie - jest zachowaniem polegającym na potwierdzaniu, przypisywaniu popełnienia zbrodni. Podkreślić należy, że niektórzy analitycy czynności sprawczej na tle przepisów art. 133 k.k. i art. 55a ustawy o IPN błędnie utożsamiają znieważenie ze zniesławieniem. Wskazówkę co do zakresów treściowych zachowania polegającego na znieważeniu oraz na zniesławieniu zawierają przepisy Kodeksu karnego odrębnie kryminalizujące zniesławienie (art. 212 k.k.) i odrębnie znieważenie (art. 216 k.k.).

Godzenie w dobre imię Narodu Polskiego i Rzeczypospolitej Polskiej przez przypisywanie im odpowiedzialności czy współodpowiedzialności za zbrodnie wskazane w art. 55a ustawy o IPN jest czynem zniesławiającym te podmioty. Ich znieważanie regulowane jest natomiast w art. 133 k.k. Kwestię tę - a więc mieszania przestępstwa znieważenia ze zniesławieniem Narodu Polskiego lub Rzeczypospolitej Polskiej i przyjmowania, że do ochrony przed zachowaniami polegającymi na zniesławieniu tych podmiotów wystarczy wyłącznie przepis art. 133 k.k. - zauważył na tle judykatury i skrytykował J. Kulesza, wskazując w czasie, gdy jeszcze nie uchwalono art. 55a ustawy o IPN - że: pomawianie Narodu Polskiego o niepopełnione zbrodnie jawi się w kategoriach niekaralnego zarzutu zniesławiającego, a nie znieważającego. (...) Zarzut dopuszczenia się przestępstwa stanowi czyn zniesławienia a nie zniewagi ${ }^{58}$. Nawiązał przy tym do uchylonego przepisu art. 132a k.k., który właśnie penalizował zniesławienie Narodu Polskiego i Rzeczypospolitej Polski. Uznał, że potwierdzeniem jego stanowiska jest projekt ustawy wprowadzający odpowiedzialność karną za przypisywanie Narodowi Polskiemu lub Państwu Polskiemu odpowiedzialności lub współodpowie-

58 J. Kulesza [w:] Kodeks karny, op. cit., s. 123. 
dzialności za zbrodnie nazistowskie określone w art. 6 Karty Międzynarodowego Trybunału Wojskowego lub za inne przestępstwa stanowiące zbrodnie przeciwko pokojowi, ludzkości lub zbrodnie wojenne lub w inny sposób rażące pomniejszanie odpowiedzialności rzeczywistych sprawców tych zbrodni ${ }^{59}$. Projekt tej ustawy został uchwalony, więc pomawianie Narodu Polskiego lub Państwa Polskiego zostało zabronione pod groźbą kary, a więc prezentowany pogląd jest aktualny.

W oczywisty sposób różni się także czynność sprawcza wskazana w art. 55 ustawy o IPN od czynności sprawczej z art. 55a tej ustawy. Według przepisu art. 55 ustawy o IPN sprawca zaprzecza zbrodniom nazistowskim i komunistycznym popełnionym na osobach narodowości polskiej lub obywatelach polskich innych narodowości w okresie od dnia 8 listopada 1917 r. do dnia 31 lipca $1990 \mathrm{r}$. lub zaprzecza innym zbrodniom przeciwko pokojowi, ludzkości lub zbrodniom wojennym. W art. 55a ustawy o IPN sprawca czynu nie tylko nie zaprzecza im, ale wręcz przypisując odpowiedzialność lub współodpowiedzialność za nie Narodowi Polskiemu lub Państwu Polskim, potwierdza ich istnienie. Przypisuje je zresztą wbrew faktom. Treść zachowania sprawcy w jednym i w drugim przypadku jest diametralnie różna, nie ma między nimi żadnych wspólnych punktów stycznych. Potwierdzanie czegoś nie jest przecież równe zaprzeczaniu tego samego. Nie na darmo przestępstwo z art. 55 ustawy o IPN nazywane jest - jak wspomniano wyżej - przestępstwem negacjonizmu. Zresztą w art. 55 ustawy o IPN chodzi o zaprzeczanie określonym zbrodniom w ogólności, bez wskazywania na ich sprawców czy na podmioty odpowiedzialne za ich popełnienie, gdyż istotą tego zachowania jest negowanie zbrodni. W art. 55a ustawy o IPN ustawodawca wyraźnie wskazał, że chodzi o przypisanie odpowiedzialności Narodowi Polskiemu lub Państwu Polskiemu. Przypisanie nie jest i nie może być równocześnie negowaniem. To, co jest zbieżne w opisie czynu zabronionego w jednym i drugim typie przestępstwa, to jedynie okoliczności modalne czynów w nich opisanych. I tu, i tu sprawca musi działać publicznie i wbrew faktom. Jednak te okoliczności przypisane są do zupełnie odmiennych zachowań. W uzasadnieniu projektu wskazano, że: [c]elem zachowania spójności systemowej projektowany art. 55 a ust. 1 ustawy odwoluje się do terminologii stosowanej $w$ art. 55 ustawy o IPN, zawierajac analogiczne znamię działania "publicznie i wbrew faktom" ${ }^{\prime \prime}$.

Tak więc, ponieważ każde ze wskazanych przestępstw zamieszczonych w art. 133 k.k., art. 55 ustawy o IPN i w art. 55a tej ustawy ma sobie tylko właściwy zakres kryminalizacji, w tym różne indywidualne dobro chronione, z każdego

59 Druk sejmowy nr 806/VIII kad.

60 Projekt ustawy o zmianie ustawy o Instytucie Pamięci Narodowej - Komisji Ścigania Zbrodni przeciwko Narodowi Polskiemu, ustawy o grobach i cmentarzach wojennych, ustawy o muzeach, ustawy o odpowiedzialności podmiotów zbiorowych za czyny zabronione pod groźbą kary oraz ustawy o zakazie propagowania komunizmu lub innego ustroju totalitarnego przez nazwy budowli, obiektów i urządzeń użyteczności publicznej, uzasadnienie, s. 4, druk sejmowy nr 806/VIII kad. 
z nich można dekodować inną normę zachowania, każdy też ma do wypełnienia inną szczegółową funkcję ochronną stawianą przed prawem karnym, a przede wszystkim każdy ze wskazanych przepisów penalizuje zasadniczo odmienny rodzaj zachowania społecznie szkodliwego - nie powinno być wątpliwości, że każdy z tych przepisów jest inny i każdy jest niezbędny dla całościowej ochrony godności Narodu Polskiego i Rzeczypospolitej Polskiej.

W zakończeniu warto jeszcze wskazać, że problem braku potrzeby wprowadzenia do prawa karnego przepisu o treści odpowiadającej przepisowi art. 55a ustawy o IPN z uwagi na - jak utrzymywano - wystarczające instrumentarium prawnokarnej ochrony tych dóbr w obowiązującym prawie karnym, podnoszony był wielokrotnie w toku prac legislacyjnych nad przepisem chroniącym dobre imię Narodu Polskiego i Rzeczypospolitej Polskiej w różnych kadencjach parlamentu. Właściwie - różnymi sposobami obalano każdą próbę wprowadzenia odrębnej ochrony Narodu Polskiego i Rzeczypospolitej Polskiej przed zniesławieniem. Przedmiotem podobnych wątpliwości był zresztą także art. 55 ustawy o IPN - też uznawany za zbędny, oraz art. 132a k.k., uchylony orzeczeniem Trybunału Konstytucyjnego. Oba te przepisy były zaskarżone przez Rzecznika Praw Obywatelskich do Trybunału Konstytucyjnego. W odniesieniu do przepisu art. 132a k.k. Rzecznik Praw Obywatelskich, który we wniosku do Trybunału Konstytucyjnego wskazał, że przedmiotem ochrony w art. 132a k.k., jest cześć i szacunek dla Narodu Polskiego, uznał, że dotychczas dobro to podlegało ochronie na podstawie art. 133 k.k., który penalizuje publiczne znieważanie Narodu lub Rzeczypospolitej Polskiej. Jak widać, RPO błędnie utożsamił znieważenie z zniesławieniem, co było treścią zaskarżonego przepisu - w każdym razie wnosił o uznanie tego przepisu za niezgodny z Konstytucją RP ${ }^{61}$.

Rzecznik Praw Obywatelskich, zaskarżając do Trybunału Konstytucyjnego także przepis art. 55 ustawy o IPN, wskazywał, że poza tym przepisem ochrona prawna demokratycznego ustroju państwa oraz bezpieczeństwa, porządku i moralności publicznej przed wskazanymi powyżej zachowaniami jest realizowana m.in. na podstawie przepisów Kodeksu karnego, w szczególności art. 256 oraz art. 257 k.k., penalizujących propagowanie faszyzmu i totalitaryzmu oraz znieważanie grupy osób lub poszczególnej osoby. Twierdził, że ewentualne uznanie niekonstytucyjności art. 55 ustawy o IPN nie spowoduje pozbawienia ochrony prawnej dóbr chronionych obecnie przez tę regulację ${ }^{62}$. Tak więc w każdej z wyżej wskazanych spraw Rzecznik Praw Obywatelskich negował potrzebę wprowadzenia odrębnego przepisu chroniącego określony aspekt godności Narodu Polskiego albo Państwa Polskiego, uważając, że wprowadzenie szczególnego, odrębnego

${ }_{61}$ Zob. P. Radziewicz, Glosa do wyroku Trybunału Konstytucyjnego z dnia 10 września 2008 r. (sygn. akt K/07), „Przegląd Sejmowy” 2009, nr 2, s. 183-197.

62 Do rozstrzygnięcia tej sprawy nie doszło, gdyż RPO 22 lutego 2011 r. wycofał wniosek w całości. 
przepisu prawnokarnego chroniącego dobre imię Narodu Polskiego i Państwa Polskiego jest zbędne, gdyż ochronę taką zapewniają inne przepisy prawa karnego.

Problem ten zupełnie inaczej został przedstawiony na tle poselskiego projektu ustawy o zmianie ustawy o IPN z $2013 \mathrm{r}^{63}$, proponującego wprowadzenie do tej ustawy art. 55a i 55b, mających służyć ochronie dobrego imienia Narodu Polskiego i Państwa Polskiego, w przywołanej wcześniej opinii do tego projektu autorstwa M. Filara i M. Berenta ${ }^{64}$. Co prawda, finalna ocena projektu sformułowana przez autorów była negatywna, ale w jej części dotyczącej przepisu odpowiadającego obecnemu art. 55a ustawy o IPN wyraźnie wskazano, że: $z a-$ bezpieczenie dóbr prawem chronionych $z$ art. 55a i 55b Projektu nie jest możliwe za pomoca innych instrumentów prawnych aniżeli $z$ zakresu prawa karnego, w szczególności niewystarczające sa instrumenty cywilno-prawne i dyplomatyczne (...). W konsekwencji powyższego stwierdzić należy, że brak jest jakichkolwiek instrumentów prawnych i pozaprawnych pozwalajacych na skuteczne zabezpieczenie dóbr prawnych, które miatby zostać objęte ochrona przez art. 55a i 55b Projektu. $W$ tym stanie rzeczy, rozpoznana społeczna szkodliwość przedmiotowych zachowań oraz brak realnej możliwości zapobieżenia im za pomoca innych środków aniżeli prawno-karnych sa zgodne z jego zasada ultima ratio $i$ - jako takie - sa zgodne $z$ art. 31 ust. 3 Konstytucji RP poprzez brak naruszenia zasady proporcjonalności, która $w$ tym przypadku nie stanowi granicy dla karalności ww. zachowań oraz wynikającej z niej zasady konieczności, skoro nie jest możliwe dobranie mniej represyjnego środka aniżeli karny dla zwalczenia niepożądanego społecznie zjawiska. Antycypując ewentualne wątpliwości, nie jest możliwa subsumpcja zachowań, dla których pole kryminalizacyjne wyznaczaja przepisy art. 55a i 55b Projektu pod jakikolwiek inny przepis prawno-karny. W sposób szczególny, mimo intuicyjnej pokusy, przepisami tymi nie są: art. 133 K.k., 255-257 K.k., art. 55 uIPN [ustawy o IPN - dopisek red.] (choć wykluczyć nie można, że w szczególnych przypadkach dojść może do zbiegu $)^{65}$. Autorzy potwierdzili zatem, że w systemie prawa karnego brak przepisów chroniących Naród Polski i Państwo Polskie przed zniesławieniem. Ten brak utrzymywał się aż do uchwalenia ustawy z 26 lutego $2018 \mathrm{r}$., ogłoszonej w Dz.U. z 14 lutego 2018 r., obowiązującej od 28 lutego 2018 r.

Reasumując, nowelizacja ustawy o IPN wprowadzająca art. 55a, kryminalizujący zniesławianie Narodu Polskiego lub Państwa Polskiego przez przypisywanie tym podmiotom odpowiedzialności lub współodpowiedzialności za określone w nim zbrodnie nazistowskie popełnione przez III Rzeszę Niemiecką lub za inne przestępstwa stanowiące zbrodnie przeciwko pokojowi, ludzkości lub zbrodnie wojenne oraz za rażące pomniejszanie odpowiedzialności rzeczywistych sprawców tych zbrodni, nie stanowi powielenia obowiązujących przepisów prawno-

63 Druk sejmowy nr 1958/VII kad.

${ }_{64}$ M. Filar, M. Berent, Opinia prawna w przedmiocie poselskiego projektu, op. cit.

65 Ibidem. 
karnych. Czyny takie nie były dotąd penalizowane przez inne przepisy - wyjąwszy krótki okres obowiązywania przepisu art. 132a k.k. Nie może zatem być mowy o multiplikacji identycznej kryminalizacji. Przepis art. 55a ustawy o IPN nie mieści się w normatywnym opisie przestępstwa $\mathrm{z}$ art. $133 \mathrm{k} . \mathrm{k}$. ani przestępstwa z art. 55 ustawy o IPN, nie może być dekodowany z żadnego z nich. Każdy $\mathrm{z}$ tych przepisów ma tylko jemu właściwy zakres penalizacji i własne pole kryminalizacji, niewystępujące w pozostałych przepisach. Dowodzą tego odrębne indywidualne przedmioty ochrony mające inną treść w każdym z tych przepisów oraz właściwa dla każdego z nich czynność sprawcza. I każdy z tych przepisów penalizuje inny rodzaj zachowania szkodliwego społecznie. Przepis art. 55a ustawy o IPN wypełnia zatem ewidentną lukę w prawnokarnej ochronie jednej z najwyższych wartości - dobrego imienia Narodu, tworzącego Rzeczpospolitą Polską, i Państwa Polskiego.

\section{Podsumowanie}

- Ustawodawca w art. 133 k.k. penalizuje zachowanie polegające na publicznym znieważeniu Narodu lub Rzeczypospolitej Polskiej. Naród - to Naród Polski rozumiany szeroko w zgodzie ze wszystkimi przepisami Konstytucji RP posługującymi się tym pojęciem. Znieważenie jest czynem polegającym na wyrażeniu pogardy dla godności Narodu Polskiego i Rzeczypospolitej Polskiej.

- Przepis art. 55 ustawy o IPN chroni pamięć zbiorową, która jest składnikiem godności Narodu i Rzeczypospolitej. Zachowaniem penalizowanym jest publiczne, wbrew faktom zaprzeczanie, a więc negowanie zbrodni nazistowskich i komunistycznych popełnionych na osobach narodowości polskiej lub obywatelach polskich innych narodowości w okresie od 8 listopada 1917 r. do 31 lipca 1990 r. lub zaprzeczanie innym przestępstwom stanowiącym zbrodnie przeciwko pokojowi, ludzkości lub zbrodnie wojenne.

- Przepis art. 55a ustawy o IPN chroni dobre imię Narodu Polskiego i Państwa Polskiego. Dobre imię jest także składnikiem ich godności. Istotą tego przestępstwa jest zniesławienie Narodu Polskiego lub Państwa Polskiego przez publiczne wbrew faktom przypisywanie tym podmiotom odpowiedzialności lub współodpowiedzialności za określone w przepisie zbrodnie.

- Każdy ze wskazanych typów rodzajowych przestępstw chroni inny aspekt godności Narodu Polskiego lub Rzeczypospolitej Polskiej. Różnią się między sobą odrębnym bezpośrednim dobrem chronionym. Każdy kryminalizuje także inny rodzaj zachowania się sprawcy. Czym innym jest znieważanie, czym innym zniesławienie i zupełnie czymś innym z punktu widzenia czynności sprawczej jest zaprzeczanie określonym zbrodniom. Zaprzeczanie nigdy nie będzie przypisywaniem, tak jak znieważanie - zniesławianiem. 
- Z każdego ze wskazanych przepisów wynika inna norma zabronionego zachowania. Zakres kryminalizacji wskazanych przepisów nie pokrywa się. Ani przepis art. 133 k.k., ani przepis art. 55 ustawy o IPN nie wyczerpuje ustawowych znamion przestępstwa $\mathrm{z}$ art. 55a ustawy o IPN.

\section{Bibliografia}

Banaszak B., Konstytucja Rzeczypospolitej Polskiej. Komentarz, Warszawa 2012.

Bojańczyk A., Opinia prawna na temat poselskiego projektu ustawy o zmianie ustawy o Instytucie Pamięci Narodowej - Komisji Ścigania Zbrodni Przeciwko Narodowi Polskiemu oraz ustawy - Kodeks karny (druk sejmowy 1958), 30 stycznia 2014 r., http://orka. sejm.gov.pl/rexdomk7.nsf/Opdodr?OpenPage\&nr=1958.

Budyn-Kulig M. [w:] Kodeks karny. Komentarz aktualizowany, red. M. Mozgawa, 2017, LEX.

Estreicher S., Zasada zwierzchnictwa narodu [w:] Nasza Konstytucja, Kraków 1922.

Filar M., Berent M., Opinia prawna w przedmiocie poselskiego projektu ustawy o zmianie ustawy o Instytucie Pamięci Narodowej - Komisji Ścigania Zbrodni przeciwko Narodowi Polskiemu oraz ustawy - Kodeks karny z 4 lutego 2014 r. (druk sejmowy 1958), http://orka.sejm.gov.pl/rexdomk7.nsf/Opdodr?OpenPage\&nr=1958.

Gałązka M. [w:] Kodeks karny. Komentarz, red. A. Grześkowiak, K. Wiak, Warszawa 2018. Giezek J., Kodeks karny. Komentarz. Część szczególna, 2008, LEX.

Glaser S., Polskie prawo karne w zarysie, Kraków 1933.

Hoc S. [w:] System prawa karnego, t. 8, red. L. Gardocki, Warszawa 2012.

Hypś S. [w:] Kodeks karny. Komentarz, red. A. Grześkowiak, K. Wiak, Warszawa 2018.

Janisławski A., Konopka P., Zagadnienie penalizacji „kłamstwa oświęcimskiego”, „Palestra” 2009, nr 1-2.

Kardas P. [w:] Kodeks karny. Komentarz do art. 117-277. Część szczególna, t. II, Warszawa 2008.

Komarnicki W., Polskie prawo polityczne, Warszawa 1922.

Konstytucja Rzeczypospolitej Polskiej. Komentarz, t. I, red. L. Garlicki, M. Zubik, Warszawa 2016.

Kulesza J. [w:] Kodeks karny. Część szczególna, t. I, Komentarz do artykułów 117-221, red. M. Królikowski, R. Zawłocki, 2017, Legalis.

Kulesza W. [w:] System prawa karnego, t. 10, red. J. Warylewski, Warszawa 2012.

Kulesza W., Wadliwe kody pamięci a zbiorowa pamięć jako dobro społeczne chronione prawem [w:] Wadliwe kody pamięci. Zniekształcenia pamięci o zbrodniach międzynarodowych $w$ dyskursie publicznym, red. A. Nowak-Far, Ł. Zamęcki, Warszawa 2015.

Kulesza W., Zniesławienie i zniewaga (Ochrona czci i godności osobistej człowieka w polskim prawie karnym - Zagadnienia podstawowe), Warszawa 1984.

Lewandowski B., Analiza art. 55 a ustawy o zmianie ustawy o IPN, http://www.ordoiuris. $\mathrm{pl} /$ dzialalnosc-instytutu/analiza-art-55a-ustawy-o-zmianie-ustawy-o-ipn. 
Makarewicz J., Kodeks karny z komentarzem, Lwów 1938.

Makowski W., Kodeks karny, Warszawa 1933.

Michalska-Warias A. [w:] Kodeks karny. Komentarz, red. T. Bojarski, Warszawa 2008.

Peiper L., Kodeks karny i prawo o wykroczeniach, Kraków 1933.

Radziewicz P., Glosa do wyroku Trybunału Konstytucyjnego z dnia 10 września 2008 r. (sygn. akt K/07), „Przegląd Sejmowy” 2009, nr 2.

Raglewski J. [w:] Kodeks karny. Część szczególna, red. A. Zoll, Warszawa 2013.

Wiak K. [w:] Kodeks karny. Komentarz, red. A. Grześkowiak, K. Wiak, Warszawa 2018.

Wojciechowska J. [w:] Kodeks karny. Komentarz, red. A. Wąsek, Warszawa 2008.

Zgoliński I. [w:] Kodeks karny. Komentarz, red. V. Konarska-Wrzosek, 2017, LEX. 